\section{Meat-free outsells beef}

Meat-free burgers made with an ingredient from genetically engineered yeast outsold ground beef burgers in US grocery stores where the two went head to head. In September, the plant-based, biotech-derived Impossible Burger began selling its uncooked product in stores for the first time. During the first two weeks, it became the overall top-selling patty fodder in many stores.

Made by Impossible Foods, the burger consists largely of soy protein, but looks, tastes and even bleeds like ground beef. Its key meaty flavor comes from heme, a molecule found abundantly in animal muscles, which Impossible scientists recreated using yeast. They fermented Pichia pastoris engineered with the gene for soy leghemoglobin, which contains heme (Nat. Biotechnol. 37, 573-480, 2019). The heme protein extract is separated and concentrated into a red liquid that, when added to soy protein and other ingredients, looks and cooks like raw ground beef. Impossible in July received FDA approval to use the red liquid as a color additive, which cleared the way for the alt-beef's debut in retail stores (Nat. Biotechnol. 37, 110, 2019). The Impossible Burger in late September appeared on the West Coast in all 27 Gelson's Markets locations, on the East Coast in all 100 Wegmans Food Market locations, and in two Fairway Market locations in New York City, according to Impossible Foods. In the first two weeks Gelson's sold more Impossible Burger than all types of ground beef in both revenue and number of pounds sold, according to the company. More than 17,000 restaurants are already selling cooked Impossible Burgers, including Burger King and Qdoba in the United States and Beef \& Liberty in Hong Kong.

Impossible is one of many groups engineering clever food ingredients. Researchers from the University of California, Berkeley on 30 September published a paper describing a way to engineer an oilseed plant to produce a human milk fat substitute for infant formula.

Published online: 5 November 2019 https://doi.org/10.1038/s41587-019-0313-x

"The pain is excruciating. It's like being in a car accident and having lightning in your chest. It's a pain that makes a grown woman like me scream." Sickle cell anemia patient Victoria Gray is the first person in the US to receive CRISPR-edited cells to induce the production of fetal hemoglobin. (NPR Shots, 10 October 2019) labeled 'early-stage', tend to want to see solid patents or patent applications, animal models, validated data, or something that is closer to the clinic, says Orin Herskowitz, executive director at Columbia Technology Ventures. Many VCs did indeed draw back from early-stage investing after 2008, but others, like Third Rock Ventures, were founded precisely to fill that gap (Nat. Biotechnol. 36, 393-401, 2018).

Where Deerfield stands out from many other VCs is in its ability to finance programs all the way. Other early-stage funders, such as London-headquartered IP Group, are going after the same perceived 'dead zone' between federal and industry funding. IP Group has relationships with six US universities, including Columbia, Princeton, University of Pennsylvania and Yale, but it is working on an entirely different scale-with fewer people, and many fewer millions. What's more, rather than selecting from scientists' proposals, as Deerfield does, "we get in there and help [scientists] work up those proposals. We think bottom-up," says Jason Smith, IP Group's Director of Life Sciences in North America.

It's all good news for translational science, says Third Rock Ventures partner Jeffrey Tong. "The availability of ideas, and capital, has accelerated significantly over the last five years," he says. The money is not necessarily being spread evenly: as VCs like Third Rock raise ever larger funds, more money is being put into the same number of projects (Nat. Biotechnol. 36, 393-401, 2018). But "I think most good ideas get funded today," claims Tong. Tech transfer executives like Herskowitz disagree, arguing that good ideas are outpacing available funding. That long-standing tension is unlikely to disappear.

In most of its academic alliances, Deerfield will share profits from any ventures equally with the institution and has the option to license any IP that emerges from the collaboration. Pre-agreed contractual terms for any startups are designed to accelerate throughput. The upside for any university startup is largely equity, rather than milestones or royalties. Flynn argues that the universities do as well, or better, under this arrangement than with traditional equity-and-royalty deals because the equity is protected from dilution, which happens as new investors are brought in. In Columbia's case, the university gets more equity than normal to begin with, and benefits from anti-dilution protection that lasts longer than post-series A, as is typical for Columbia, according to Herskowitz.

Deerfield's experts span diverse backgrounds-from academia, biotech and big pharma to contract research organizations-but each alliance has an on-campus CSO. These CSOs typically have 20 years' or more experience in drug discovery as a front-line manager. Mike Foley is orchestrating discovery across all the academic alliances; he was previously a director at the Broad Institute, with which Deerfield has been collaborating since 2017.

Real estate is also part of Deerfield's ambition, as the recent New York infrastructure deal reveals. The group acquired real estate on Park Avenue South in Manhattan, where it aims to create the 300,000 square feet of life sciences campus, working with the New York City Economic Development Corporation. The space, expected to open in early 2021, will house Deerfield's own offices, plus lab and digital space for life sciences and technology companies and incubator and accelerator facilities for entrepreneurs. "It is designed to be a hub for healthcare innovation that will leverage our academic relationships and our [wider] investments in healthcare companies," says Flynn.

Such a move puts Deerfield in competition with Alexandria Real Estate, which also builds incubators and provides seed funding in NY. Two years ago it opened the Alexandria Center for Life Sciences in Manhattan, and the Alexandria LaunchLabs @ Columbia is due to open in the Spring of 2020 on the university campus. Deerfield also invested $\$ 275$ to create a medical devices incubator, NXT Biomedical, in 2018 with Stan Rowe, previously CSO at Edwards Lifesciences.

Deerfield hopes to take full advantage of its growing network of academic alliances. "We may discover something at the Broad, something at John Hopkins or at Chapel Hill, and bring these together and build a management team around them to create critical mass," says Flynn. The Broad, Deerfield's first alliance partner, has four projects under management and has generated two spinouts since the 2017 tie-up.

Meanwhile, Deerfield's investment activities look set to continue all along the spectrum from public equity and debt to crossover, seed and everything in between. They still typically hold equity or debt interests in over 100 public companies at any one time. "We see ourselves as an information-based firm that does the optimized thing based on the information we see," says Flynn.

\section{Melanie Senior}

London, UK

Published online: 8 October 2019

https://doi.org/10.1038/d41587-019-00031-6 